\title{
Synthesis, characterisation and biological studies of mixed-ligand nickel (II) complexes containing imidazole derivatives and thiosemicarbazide Schiff bases
}

\author{
Nurul N. M. Ishak ${ }^{a}$, Junita Jamsaria ${ }^{a}$ A. Z. Ismaila, Mohamed I. M. Tahir ${ }^{a}$, Edward R.T. \\ Tiekink $^{\mathrm{b}}$, Abhi Veerakumarasivam ${ }^{\mathrm{c}, \mathrm{d}}$, Thahira B.S.A. Ravoof $*$ a,e \\ ${ }^{a}$ Department of Chemistry, Faculty of Science, Universiti Putra Malaysia, 43400 UPM Serdang, Selangor \\ Darul Ehsan, Malaysia \\ ${ }^{b}$ Research Centre for Crystalline Materials, School of Science and Technology, Sunway University, No. 5 \\ Jalan Universiti, 47500 Bandar Sunway, Selangor Darul Ehsan, Malaysia \\ ${ }^{c}$ Department of Biological Sciences, School of Science and Technology, Sunway University, No. 5 Jalan \\ Universiti, 47500 Bandar Sunway, Selangor Darul Ehsan, Malaysia \\ ${ }^{d}$ Medical Genetics Laboratory, Faculty of Medicine and Health Sciences, Universiti Putra Malaysia, 43400 \\ UPM Serdang, Selangor Darul Ehsan, Malaysia \\ ${ }^{e}$ Materials Synthesis and Characterization Laboratory, Institute of Advanced Technology, Universiti Putra \\ Malaysia, 43400 UPM Serdang, Selangor Darul Ehsan, Malaysia
}

*corresponding author: thahira@upm.edu.my

\begin{abstract}
Four new mixed-ligand $\mathrm{Ni}(\mathrm{II})$ complexes (1-4) containing imidazole (im) or benzimidazole (bz) and tridentate Schiff bases derived from 2,4-dihydroxybenzaldehyde (24D) and 4-methyl-3thiosemicarbazide (MT24D) or 4-phenyl-3-thiosemicarbazide (PT24D) were synthesised and characterised using elemental and spectral analysis including FTIR, UV-Vis, ${ }^{1} \mathrm{H}$ NMR, ${ }^{13} \mathrm{C}\left\{{ }^{1} \mathrm{H}\right\}$ NMR and mass spectrometry for Schiff bases, while the complexes were additionally analysed
\end{abstract}


using ICP-OES, molar conductivity, magnetic susceptibility measurements and single crystal XRay diffraction (SXRD) analysis. Magnetic susceptibility indicated a square planar geometry for all the metal complexes while molar conductance values showed that the complexes were nonelectrolytes in DMSO. The molecular geometries of the neutral complex molecule in [Ni(PT24D)(bz)](bz). $\mathrm{CH}_{3} \mathrm{OH}\left(\mathbf{2}^{\prime}\right)$, that is $\mathbf{2}$ co-crystallised with a 1,3-benzimidazole molecule as a methanol solvate, and in the cation of $[\mathrm{Ni}(\mathrm{MT} 24 \mathrm{D})(\mathrm{im})] \mathrm{O}_{2} \mathrm{CMe} \cdot 2 \mathrm{H}_{2} \mathrm{O}$ (5), a reaction intermediate for $\mathbf{1}$, were established by X-ray crystallography. Each featured a trans- $\mathrm{N}_{2} \mathrm{OS}$ coordination geometry defined by phenoxide-O, imine-N and thiolate-S (2') or thione-S (5) donors as well as the imine-N donors derived from 1,3-benzimidazole (2') or imidazole (5) molecules. Systematic variations in geometric parameters were correlated with the form of the tridentate ligand, i.e. di-anionic (2') or mono-anionic (5). In the crystal of $\mathbf{2}^{\prime}$, supramolecular chains are sustained by hydrogen bonding and these were connected into a supramolecular layer by $\pi \cdots \pi$ stacking interactions occurring between coordinated benzimidazole rings. In the crystal of $\mathbf{5}$, hydrogen bonding leads to a three-dimensional architecture. By contrast, the Schiff bases and mixed-ligand $\mathrm{Ni}$ (II) complexes were tested for their cytotoxic activities, but all compounds were inactive against the tested breast cancer cell lines of MDA-MB-231 and MCF-7. Interestingly, the antibacterial analysis of the compounds showed that the PT24D Schiff base, Ni(MT24D)im, Ni(MT24D)bz, and Ni(PT24D)bz complexes had specific and selective activity against Staphylococcus aureus (S. aureus), Bacillus subtilis (B. subtilis), Propionibacterium acne (P. acne) and Enterobacteraerogenes (E. aerogenes). The DNA binding studies of mixedligand $\mathrm{Ni}(\mathrm{II})$ complexes against calf thymus DNA revealed that slight hypochromism was observed in the absorption spectra suggesting $\pi-\pi$ interactions between the aromatic 
chromophores and the DNA base pairs where 2 had higher $\mathrm{K}_{\mathrm{b}}$ values than $\mathbf{1}$ indicating stronger interactions.

\section{Introduction}

In recent years, multi-drug resistance has become a serious issue resulting in failure of treatment due to resistance against currently available drugs. Therefore, the study of using transition metal complexes as metallo-drugs is believed to have great potential in wiping out the microbial menace by using different therapeutic approaches [1-2]. Small molecules like transition metal complexes have been proven to have strong binding interactions with DNA via both covalent and non-covalent interaction modes. The interaction modes play a significant role in the biological activities of metal complexes especially as antibacterial, antifungal and anticancer agents [3]. For example, the $\mathrm{Cu}$ (II) Schiff base complex derived from 4-chloroanthranilic and salicylaldehyde showed an intercalative binding mode with CT-DNA with a high $K_{\mathrm{b}}$ constant of $1.93 \times 10^{4} \mathrm{~L}$ $\mathrm{mol}^{-1}$, indicative of strong binding, as compared to other similar complexes such as $[\mathrm{Cu}(\mathrm{naph}-$ leu)phen $] \mathrm{CH}_{3} \mathrm{OH} \cdot 0.5 \mathrm{H}_{2} \mathrm{O} \quad\left(K_{\mathrm{b}}, \quad 4.87 \times 10^{3} \mathrm{~L} \mathrm{~mol}^{-1}\right) \quad$ and $\quad[\mathrm{Cu}(\mathrm{sal}-\mathrm{L}-\mathrm{val})$ phen $] \quad\left(K_{\mathrm{b}}\right.$,

$6.48 \times 10^{3} \mathrm{~L} \mathrm{~mol}^{-1}$ ) [4]. This has formed the basis of most research in the synthesis of metal complexes via various methods and different designs to develop new metal-based drugs.

Transition metal complexes of thiosemicarbazone ligands have received considerable interest due to its ability to disrupt DNA synthesis by causing modification in the reductive conversion of ribonucleotides to deoxyribonucleotides [5]. Furthermore, by introducing aldehydes or ketones to thiosemicarbazones, the Schiff bases that are formed can interact with metal ions to form complexes that have stable four, five or six coordination $[6,7]$. The biological activity of thiosemicarbazones are affected by their chelating ability with transition metal ions. Coordination to metal centre through sulfur and nitrogen donors would form bidentate, tridentate 
or even multidentate ligands, thus giving rise to complexes of different geometries and properties that would alter or enhancing their biological properties [8-11, 12]. Studies also reported that the biological activity of the metal complexes of thiosemicarbazone-derived Schiff bases often had higher, and selective bioactivities as compared to the corresponding free thiosemicarbazones [1315]. The biological activity of these metal complexes containing Schiff bases have also been reported to have enhanced activities when ligated to a co-ligand, forming mixed-ligand complexes. For instance, the $\mathrm{Cu}(\mathrm{II})$ complexes of a tridentate Schiff base, salicylaldehyde-4methyl-3-thiosemicarbazone in the presence of imidazole or benzimidazole indicated enhanced activity against MCF-7 and MDA-MD-231 breast cancer cell lines [16] as compared to the mono-ligand metal complex.

Imidazole derivatives are an important class of heterocycles, being the core fragment of different natural products and biological systems. The imidazole ring is biologically relevant as it can mimic the histidine moiety. It is able to act as a co-ligand in metal complexes, potentially enabling them to bind with biomolecules [17]. They occupy a unique place in the field of medicinal chemistry owing to their potent biological activity especially as antiprotozoal, antifungal, and antihypertensive agents [18, 19-21]. Bearing donors and acceptors capable of hydrogen bonding, imidazole- and benzimidazole- containing metal complexes often possess interesting supramolecular architectures [22]. In the study of imidazole derivatives [23], Brandenburg reported that the compound synthesized from $\mathrm{Cu}(\mathrm{II})$ with salicylideneanthranilic acid and a co-ligand 2-methylimidazole $[\mathrm{Cu}(\mathrm{SAA})(\mathrm{MeImH})]$ had distinct superoxide dismutase activity (SOD) which yielded 50\% inhibition of the reduction of NBT $\left(\mathrm{IC}_{50}=35 \mu \mathrm{mol} \mathrm{dm}{ }^{-3}\right)$ higher than native enzyme as the standard $\left(\mathrm{IC}_{50}=0.004 \mu \mathrm{mol} \mathrm{dm}{ }^{-3}\right)$. This higher $\mathrm{IC}_{50}$ value was 
hypothesized to be due to the strong ligand field created by the tridentate Schiff base that would interfere with the interaction of the complexed copper ion with the superoxide radicals [24].

In the present study, a new series of mixed-ligand metal complexes were formed by reacting single atom donor ligands, imidazole and benzimidazole with tridentate thiosemicarbazide Schiff bases and Ni(II) acetate. Since scarce information has been reported on mixed ligand metal complexes containing imidazole derivatives as a co-ligand and in view of the reports on the biological relevance of related mixed-ligand metal complexes, we report herein the synthesis, characterisation, cytotoxicity, antibacterial activity and DNA-binding studies of mixed ligand metal complexes derived from tridentate ONS Schiff bases with imidazole derivatives.

\section{Experimental}

\subsection{Instrumentation and materials}

All chemicals were of analytical grade (A.R. from Alfa Aesar, Aldrich or Merck) and used without further purification. Elemental analysis $(\mathrm{C}, \mathrm{H}, \mathrm{N})$ were performed using a LECO CHNS-932 elemental analyser. Infrared (IR) spectra were recorded on PerkinElmer 100 spectrophotometer $\left(4000-280 \mathrm{~cm}^{-1}\right)$. Molar conductance of $10^{-3} \mathrm{M}$ solutions of the mixed-ligand $\mathrm{Ni}(\mathrm{II})$ complexes in DMSO were measured using a Jenway 4310 conductivity meter with a dip-type cell electrode. Magnetic susceptibility was measured with a Sherwood Scientific MSB-AUTO magnetic susceptibility balance at $298 \mathrm{~K}$. UV-Vis spectra were recorded by using a Shimadzu UV-2501 PC recording spectrophotometer in the range of 1000-200 $\mathrm{nm}$. Metal content of the complexes were

determined using Inductive Coupled Plasma-Optical Emission Spectrometry. Nuclear 
Magnetic Resonance $\left({ }^{1} \mathrm{H}\right.$ NMR and ${ }^{13} \mathrm{C}$ NMR) spectra were recorded using an JNM ECA400 NMR spectrometer.

2.2 Synthesis of 4-methyl-3-thiosemicarbazide-2,4-dihydroxybenzaldehyde (MT24D) and 4phenyl-3-thiosemicarbazide-2,4-dihydroxybenzaldehyde (PT24D).

$20 \mathrm{mmol}(2.76 \mathrm{~g})$ of 2,4-dihydroxybenzaldehyde was dissolved in $30 \mathrm{ml}$ ethanol and added to an equimolar solution of 4-methyl-3-thiosemicarbazide (20mmol, $2.10 \mathrm{~g}$ ) or 4-phenyl3-thiosemicarbazide (20 mmol, $3.34 \mathrm{~g})$ in the same solvent. The mixture was stirred and reduced to half volume from initial volume. The precipitate that formed was recrystallised with cold ethanol. The yields were dried over silica gel overnight.

For MT24D. Yield: (86\%). Colour: light yellow, melting point: $215-216^{\circ} \mathrm{C}$. Anal. Calc. For $\left[\mathrm{C}_{9} \mathrm{H}_{11} \mathrm{~N}_{3} \Theta_{2} \mathrm{~S}\right] \mathrm{C}, 47.9 ; \mathrm{H}, 4.9 ; \mathrm{N}, 18.6$. Found $\mathrm{C}, 47.2 ; \mathrm{H}, 5.0 ; \mathrm{N}, 18.6$.data are given in Table 2 IR, ATR $v\left(\mathrm{~cm}^{-1}\right): 3240 v(\mathrm{O}-\mathrm{H}), 3336 v(\mathrm{~N}-\mathrm{H}), 1616 v(\mathrm{C}=\mathrm{N}), 1013 v(\mathrm{~N}-\mathrm{N}), 866 v(\mathrm{C}=\mathrm{S})$. ${ }^{1} \mathrm{H}$ NMR (400 MHz, DMSO-d6, $\delta$ ppm): 11.41 (s, 1H, NH), 9.45 (q, 1H, J = 32 Hz, NH), 8.37 (s, 1H, CH), 8.35 (s, 2H, OH phenolic), 7.33 (d, 1H, J = 4 Hz, Ar H), 6.74 (d, 1H, J = $8 \mathrm{~Hz}, \mathrm{Ar} H)$, $6.62(\mathrm{t}, 1 \mathrm{H}, \mathrm{J}=24 \mathrm{~Hz}, \mathrm{Ar} \mathrm{H}), 2.45\left(\mathrm{~d}, 3 \mathrm{H}, \mathrm{J}=12 \mathrm{~Hz}, \mathrm{CH}_{3}\right) .{ }^{13} \mathrm{C}$ NMR (100 MHz, DMSO-d6, $\delta$ ppm): 177.12 (C8), 146.11 (C5), 144.67 (C3), 140.56 (C7), 121.45 (C6), 118.87 (C4), 116.98 (C1), 116.85 (C2), 31.38 (C9). MS m/z $225(\mathrm{M}+1)$.

For PT24D. Yield: (89\%). Colour: yellow, melting point: $205-206{ }^{\circ} \mathrm{C}$. Anal. Calc. For $\left[\mathrm{C}_{14} \mathrm{H}_{43} \mathrm{~N}_{3} \mathrm{O}_{2} \mathrm{~S}\right] \mathrm{C}, 58.5 ; \mathrm{H}, 4.6 ; \mathrm{N}, 14.6$. Found $\mathrm{C}, 58.6 ; \mathrm{H}, 4.9 ; \mathrm{N}, 14.7$.data are given in Table 2. IR, ATR $v\left(\mathrm{~cm}^{-1}\right): 3160 v(\mathrm{O}-\mathrm{H}), 3240 v(\mathrm{~N}-\mathrm{H}), 1592 v(\mathrm{C}=\mathrm{N}), 1022 v(\mathrm{~N}-\mathrm{N}), 825 v(\mathrm{C}=\mathrm{S}) .{ }^{1} \mathrm{H}$ NMR (400 MHz, DMSO-d6, $\delta$ ppm): $11.71(\mathrm{~s}, 1 \mathrm{H}, \mathrm{NH}), 9.96$ (s, 1H, OH phenolic), 9.55 (s, 1H, OH 
phenolic), $8.94(\mathrm{q}, 1 \mathrm{H}, \mathrm{J}=32 \mathrm{~Hz}, \mathrm{NH}), 8.43(\mathrm{~s}, 1 \mathrm{H}, \mathrm{CH}), 7.51(\mathrm{~d}, 2 \mathrm{H}, \mathrm{J}=8 \mathrm{~Hz}, \mathrm{Ar} \mathrm{H}), 7.49$ (d, $1 \mathrm{H}, \mathrm{J}=12 \mathrm{~Hz}, \operatorname{Ar~H}), 7.33$ (t, 2H, J = $16 \mathrm{~Hz}, \operatorname{Ar~H}), 7.14(\mathrm{t}, 1 \mathrm{H}, \mathrm{J}=16 \mathrm{~Hz}, \operatorname{Ar~H}), 6.78(\mathrm{~d}, 1 \mathrm{H}, \mathrm{J}$ $=16 \mathrm{~Hz}, \mathrm{Ar} \mathrm{H}), 6.64$ (t, $1 \mathrm{H}, \mathrm{J}=12 \mathrm{~Hz}, \mathrm{Ar} \mathrm{H}) \cdot{ }^{13} \mathrm{C}$ NMR (100 MHz, DMSO- $\left.d 6, \delta \mathrm{ppm}\right): 176.23$ (C8), 146.13 (C5), 145.39 (C3), 141.76 (C7), 139.68 (C9), 128 (C10, C14), 126.23 (C10, C11), 125.57 (C1), 121.54 (C6), 119.40 (C4), 118.59 (C2), 117.20 (C12). MS m/z 287 (M+1).

\subsection{Synthesis of mixed-ligand $\mathrm{Ni}(\mathrm{II})$ complexes (1-4)}

$2 \mathrm{mmol}(0.43 \mathrm{~g}) \mathrm{Ni}\left(\mathrm{CH}_{3} \mathrm{COO}\right)_{2} \cdot \mathrm{H}_{2} \mathrm{O}$ was dissolved in $20 \mathrm{ml}$ of methanol. $8 \mathrm{mmol}(0.54$ g) imidazole or benzimidazole $(8 \mathrm{mmol}, 0.95 \mathrm{~g})$ in $30 \mathrm{ml}$ dichloromethane was added to this solution. The mixture was stirred and heated for about 20 minutes. A solution of Schiff base, MT24D (2 mmol, $0.45 \mathrm{~g}$ ) or PT24D (2 mmol, $0.57 \mathrm{~g}$ ) was added to the metal-imidazole solution. The mixture was heated while stirring to reduce the volume to half. The precipitate formed when the mixture was cooled to room temperature, filtered and dried over silica gel overnight. For imidazole or benzimidazole to remain as a co-ligand, a large excess eencentration was added in the reaction. A small amount of crystals suitable for single crystal $X$ ray structure analysis were obtained for 1 and 2 after slow evaporation in acetonitrile for a week.

2.4 Single Crystal X-ray structure determination of $[\mathrm{Ni}(\mathrm{PT} 24 \mathrm{D})(\mathrm{bz})](\mathrm{bz}) \cdot \mathrm{CH}_{3} \mathrm{OH}\left(2^{\prime}\right)$, and in the cation of $[\mathrm{Ni}(\mathrm{MT} 24 \mathrm{D})(\mathrm{im})] \mathrm{O}_{2} \mathrm{CMe} .2 \mathrm{H}_{2} \mathrm{O}(5)$

In addition to crystals of $\mathbf{2}^{\prime}$, that is $\mathbf{2}$ co-crystallised with a 1,3-benzimidazole molecule as a methanol solvate, a small number of crystals of a reaction intermediate isolated from the reaction mixture of $\mathbf{1}$ were isolated and characterised crystallographically, hereafter $\mathbf{5}$. Intensity data for $\mathbf{2}^{\prime}$ and $\mathbf{5}$ were measured at $\mathrm{T}=100 \mathrm{~K}$ on an Oxford Diffraction Gemini Eos CCD 
diffractometer fitted with Mo K $\alpha$ radiation $(\lambda=0.71073 \AA)$. Data reduction, including analytical absorption correction, was accomplished with CrysAlisPro [25]. The structures were solved by direct-methods [26] and refined (anisotropic displacement parameters, C-bound $\mathrm{H}$ atoms in the riding model approximation) on $F^{2}$ [27]. The oxygen and nitrogen-bound hydrogen atoms were located from Fourier difference maps but refined with distance restraints $\mathrm{O}-\mathrm{H}=0.84 \pm 0.01 \AA$ and $\mathrm{N}-\mathrm{H}=0.88 \pm 0.01 \AA$, respectively. The only exception to this was for the $\mathrm{O} 2 \mathrm{w}$-water-bound hydrogen atoms in $\mathbf{5}$ which were included in their as-located positions constrained to $\mathrm{O}-\mathrm{H}=0.83$ $\AA$ A. Even restrained refinement of this water molecule proved unstable, an observation correlated with the relatively large displacement parameters associated with the $\mathrm{O} 2 \mathrm{w}$ oxygen atom. A consequence of this is that one of the hydrogen bonds formed by this water molecule is rather weak; it should be noted that the next closest potential acceptor atom for a hydrogen bond is 3.83 $\AA$ distant. A weighting scheme $w=1 /\left[\sigma^{2}\left(F_{\mathrm{o}}{ }^{2}\right)+(a P)^{2}+b P\right]$ where $\left.P=\left(F_{\mathrm{o}}{ }^{2}+2 F_{\mathrm{c}}{ }^{2}\right) / 3\right)$ was introduced in each case. In the final cycles of the refinement of 5, a reflection, i.e. (-6 -4 8), was omitted owing to poor agreement. The molecular structure diagrams was generated with ORTEP for Windows [28] with $70 \%$ displacement ellipsoids and the packing diagrams were drawn with DIAMOND [29]. Additional data analysis was made with PLATON [30]. Crystal data and refinement details are given in Table 1.

\section{Table 1}

Crystal data and refinement details for complexes $\mathbf{2}$ and $\mathbf{5}$.

\begin{tabular}{lll}
\hline Complex & $\mathbf{2}$ & $\mathbf{5}$ \\
\hline Formula & $\mathrm{C}_{16} \mathrm{H}_{15} \mathrm{~N}_{5} \mathrm{NiO}_{2} \mathrm{~S}, \mathrm{C}_{7} \mathrm{H}_{6} \mathrm{~N}_{2}, \mathrm{CH}_{4} \mathrm{O}$ & $\mathrm{C}_{12} \mathrm{H}_{14} \mathrm{~N}_{5} \mathrm{NiO}_{2} \mathrm{~S}, \mathrm{C}_{2} \mathrm{H}_{3} \mathrm{O}_{2} .2 \mathrm{H}_{2} \mathrm{O}$ \\
Formula weight & 550.28 & 446.13
\end{tabular}




\begin{tabular}{|c|c|c|}
\hline Crystal colour & green & brown \\
\hline Crystal system & Triclinic & Triclinic \\
\hline Space group & $P 1$ & $P 1$ \\
\hline$a / \AA$ & $9.9399(6)$ & $7.8339(7)$ \\
\hline$b / \AA$ & $10.4759(7)$ & $10.6523(8)$ \\
\hline$c / \AA$ & $12.0659(7)$ & $11.8297(7)$ \\
\hline$\alpha l^{\circ}$ & $99.237(5)$ & $98.363(5)$ \\
\hline$\beta /^{\circ}$ & $93.911(5)$ & $101.635(6)$ \\
\hline$\gamma^{\circ}$ & $95.581(5)$ & $100.212(7)$ \\
\hline$V / \AA^{3}$ & $1229.74(13)$ & $934.61(13)$ \\
\hline$Z$ & 2 & 2 \\
\hline$D_{\mathrm{c}} / \mathrm{g} \mathrm{cm}^{-3}$ & 1.486 & 1.585 \\
\hline$F(000)$ & 572 & 464 \\
\hline$\mu(\mathrm{MoK \alpha}) / \mathrm{mm}^{-1}$ & 0.915 & 1.192 \\
\hline Measured data & 10943 & 8119 \\
\hline$\theta$ range $^{\circ}$ & $2.4-25.2$ & $2.4-25.2$ \\
\hline Unique data & 5562 & 4206 \\
\hline Observed data $(I \geq 2.0 \sigma(I))$ & 4207 & 3531 \\
\hline No. parameters & 342 & 264 \\
\hline$R$, obs. data; all data & $0.045 ; 0.100$ & $0.042 ; 0.099$ \\
\hline$a ; b$ in weighting scheme & $0.051 ; 0.257$ & $0.047 ; 0.550$ \\
\hline$R_{\mathrm{w}}$, obs. data; all data & $0.069 ; 0.112$ & $0.053 ; 0.106$ \\
\hline $\mathrm{GoF}$ & 1.05 & 1.04 \\
\hline \multicolumn{3}{|l|}{ Range of residual electron } \\
\hline density peaks/e $\AA^{-3}$ & $-0.40-0.57$ & $-0.48-0.96$ \\
\hline
\end{tabular}




\subsection{Bioactivity}

\subsubsection{Cytotoxicity assays}

MDA-MB-231 (estrogen receptor-negative human breast cancer cells) and MCF-7 (estrogen receptor-positive human breast cancer cells) cell lines were obtained from the National Cancer Institute, USA. The cells were cultured in tissue culture flasks containing RPMI 1640 culture medium supplemented with $1 \%$ penicillin and $10 \%$ fetal bovine serum (FBS). The cytotoxicity was determined by using the 3-(4,5-dimethylthiazol-2-yl)-2,5-diphenyltetrazolium bromide (MTT) assay [31]. Cytotoxicity was expressed as $\mathrm{IC}_{50}$ which is the concentration of trial compound that inhibits the cancer cells by $50 \%$ as compared to the control. The control that contained untreated cells were included for each sample. Tamoxifen was used as a standard drug.

\subsubsection{Antibacterial activity}

Clinical isolates of the following organisms: Methicillin Resistant Staphylococcus aureus (MRSA), Staphylococcus aureus, Bacillus subtilis, Serratiamarcescens, Propionibacterium acne, Pseudomonas aeruginosa and Enterobacteraerogenes used in this study were obtained from the culture collection of the Institute of Bioscience, UPM. The bacterial strains were grown and maintained on nutrient agar (NA) slant. Antimicrobial activity was based on a clear zone formed around the disc. Complete inhibition was indicated by a clear zone, while partial inhibition was by a semi-clear zone. Streptomycin $(100 \mathrm{mg} / \mathrm{mL})$ was used as the reference drug for antibacterial activity with DMSO as the negative control. The bacterial suspension $\left(10^{8} \mathrm{cfu} / \mathrm{mL}\right)$ was inoculated onto the entire surface of a nutrient agar (NA) plate with a sterile cotton-tipped swab to form an even lawn. After solidification, the filter paper discs impregnated with the extracts 
were placed on the NA plates. The plates were then incubated at $37{ }^{\circ} \mathrm{C}$ for $18-24$ hours. All tests were performed in triplicate and the antibacterial activity was expressed as the mean of the inhibition diameters $(\mathrm{mm})$ obtained.

\subsubsection{Determination of minimum inhibitory concentration (MIC)}

The MIC values were determined by the liquid dilution method [32] for samples that displayed inhibition zones of around $15 \mathrm{~mm}$ and more in the disc diffusion assay. Various concentrations of each sample (ranging from $0.156-20 \mathrm{mg} / \mathrm{mL}$ ) were prepared in 96-microwell plates followed by inoculating $10 \mu \mathrm{l}$ of the standardized suspension bacteria. The microwell plates were incubated at $37^{0} \mathrm{C}$ for $18-24$ hours. The MICs of the samples were recorded as the lowest concentration that could inhibit the visible growth of microorganisms overnight. Each experiment was carried out three times and was correlated against the controls.

\subsubsection{Determination of minimum bactericidal concentrations $(M B C)$}

A loopful of sample from each well in the MIC examination which did not show any growth was inoculated on NA and incubated at $37^{\circ} \mathrm{C}$ for $18-24$ hours. In this test, the lowest concentration of sample required to kill a particular bacterium was determined as the MBC.

\subsubsection{DNA-binding study}

The buffer solution was prepared by adding $5 \mathrm{mM}$ Tris-HCl (Sigma Aldrich) and 25 $\mathrm{mM} \mathrm{NaCl}$ (Sigma Aldrich) in $500 \mathrm{ml}$ ultrapure water $(\mathrm{pH}=7.1)$. The CT-DNA was dissolved in $25 \mathrm{ml}$ of buffer solution [33]. The concentration of CT-DNA was calculated 
according to Beer-Lambert's Law $A=\varepsilon b c$, where $\varepsilon$ is the molar extinction coefficient, 6600 $\mathrm{M}^{-1} \mathrm{~cm}^{-1}$ at $260 \mathrm{~nm}$ [34]. The calculated DNA concentration was $5.136 \times 10^{-5} \mathrm{M}$. The complexes were dissolved in a mixture of DMSO/buffer (3:7). Absorption titration measurements were carried out by gradually increasing the DNA concentration while maintaining the complex concentration $\left(2 \times 10^{-6} \mathrm{M}\right)$. Absorbance values were recorded after each successive addition of DNA solution and equilibration using UV spectrophotometry [35].

\section{Results and discussion}

Schiff bases (MT24D and PT24D) were prepared by the condensation reaction of 2,4dihydroxybenzaldehyde with 4-methyl-3-thiosemicarbazide and 4-phenyl-3-thiosemicarbazide to form uninegatively-charged tridentate Schiff bases. The mixed-ligand Ni(II) complexes (1-4) were synthesized by reacting $\mathrm{Ni}$ (II) acetate, imidazole/benzimidazole (excess) and the Schiff bases in a one-pot reaction. The Schiff bases and mixed-ligand $\mathrm{Ni}$ (II) complexes were obtained in good yields with sharp melting points indicating that the compounds were relatively free of impurities. The Schiff bases were soluble in most common organic solvents while the mixedligand $\mathrm{Ni(II)} \mathrm{complexes} \mathrm{had} \mathrm{limited} \mathrm{solubility,} \mathrm{and} \mathrm{were} \mathrm{only} \mathrm{completely} \mathrm{soluble} \mathrm{in} \mathrm{DMSO} \mathrm{and}$ THF. The physical properties and elemental analyses obtained for the Schiff bases and mixedligand $\mathrm{Ni}(\mathrm{II})$ complexes are listed in Table 2. All physiochemical and spectroscopic analyses were carried out on the bulk samples.

\subsection{Magnetic and conductivity data}


All the mixed-ligand $\mathrm{Ni}(\mathrm{II})$ complexes exhibited diamagnetic properties which was indicative of $d^{8} \mathrm{Ni}(\mathrm{II})$ complex with a square planar geometry [3] since the Schiff bases were expected to coordinate with the metal atom through three donor atoms while imidazole or benzimidazole occupied the fourth position. The complexes were non-electrolytes in DMSO [36], which fell in the range of 2.3-3.3 $\Omega^{-1} \mathrm{~cm}^{2} \mathrm{~mol}^{-1}$, indicating that both imidazole/benzimidazole and ligand did not exist as free ions in solution. 


\section{Table 2}

Physical properties and elemental analysis of the Schiff bases and mixed-ligand Ni(II) complexes.

\begin{tabular}{|c|c|c|c|c|c|c|c|c|}
\hline \multirow{2}{*}{$\begin{array}{l}\text { Compound (Mol. } \\
\text { Wt.) }\end{array}$} & \multirow{2}{*}{ Color } & \multirow{2}{*}{ M.P $\left({ }^{\circ} \mathrm{C}\right)$} & \multirow{2}{*}{$\Lambda^{\mathrm{a}}$} & \multirow{2}{*}{$\mu^{\mathrm{b}}(\mathrm{B} . \mathrm{M})$} & \multicolumn{4}{|c|}{ (\%) Found (Calcd.) } \\
\hline & & & & & $\mathrm{C}$ & $\mathrm{H}$ & $\mathrm{N}$ & $\mathrm{M}$ \\
\hline MT24D (225.0) & Light yellow & $215-216$ & 3.3 & - & $47.2(47.9)$ & $5.0(4.9)$ & $18.6(18.6)$ & - \\
\hline PT24D (287.3) & Yellow & $126-127$ & 2.3 & - & $58.6(58.5)$ & $4.9(4.6)$ & $14.7(14.6)$ & - \\
\hline $\begin{array}{l}\text { Ni(MT24D)im (1) } \\
(349.0)\end{array}$ & Brown & $>300$ & 2.5 & Diamagnetic & $41.9(41.2)$ & $4.1(3.7)$ & $20.7(20.0)$ & $16.2(16.7)$ \\
\hline $\begin{array}{l}\text { Ni(MT24D)bz (2) } \\
(399.0)\end{array}$ & Brown & $>300$ & 2.4 & Diamagnetic & $48.3(48.0)$ & $4.3(3.8)$ & $17.8(17.5)$ & $14.3(14.6)$ \\
\hline $\begin{array}{l}\text { Ni(PT24D)im (3) } \\
(411.0)\end{array}$ & Dark brown & $>300$ & 2.9 & Diamagnetic & $50.5(49.9)$ & $4.0(3.6)$ & $16.6(16.9)$ & $14.8(14.2)$ \\
\hline $\begin{array}{l}\mathrm{Ni}(\mathrm{PT} 24 \mathrm{D}) \mathrm{bz}(\mathbf{4}) \\
(461.0)\end{array}$ & Brown & $>300$ & 3.5 & Diamagnetic & $54.2(54.5)$ & $3.9(3.7)$ & $15.4(15.1)$ & $12.9(12.7)$ \\
\hline
\end{tabular}

${ }^{\mathrm{a}}$ Molar conductance $\left(\Omega^{-1} \mathrm{~cm}^{2} \mathrm{~mol}^{-1}\right)$ of $10^{-3} \mathrm{M}$ solutions in DMSO

${ }^{\mathrm{b}}$ Magnetic moments at $298 \mathrm{~K}$ 


\subsection{Electronic and IR spectra}

The infrared spectral data for the ligand and metal complexes are shown in Table 3 and Figs. S1, S2 and S3 (Supplementary file). Both ligands successfully coordinated to the metal ion through the phenoxide-oxygen, azomethine-nitrogen, and thiolate-sulphur atoms as evidenced by shift of wavenumbers of certain key functional groups in the IR spectra. The absence of the $v(\mathrm{~S}-$ $\mathrm{H}$ ) band at $2570 \mathrm{~cm}^{-1}$ in the spectra of the ligands indicated that they existed as the thione form in the solid-state [35]. The thione forms are unstable and tend to convert to stable thiolo forms in the presence of metal ions, by enethiolization in solution [37]. In the infrared spectrum of MT24D and PT24D ligands, strong bands were observed at $1616 \mathrm{~cm}^{-1}$ and $1592 \mathrm{~cm}^{-1}$ respectively, representing $v(\mathrm{C}=\mathrm{N})$ and these bands shifted to lower wavenumbers indicating that the metal ions coordinated through the azomethine-nitrogen. A weak $v(\mathrm{C}=\mathrm{N})$ band from imidazole or benzimidazole appeared in the region 1699-1748 $\mathrm{cm}^{-1}$ indicative of their presence as a co-ligand. A broad $v(\mathrm{O}-\mathrm{H})$ band was seen in the region of $3049-3240 \mathrm{~cm}^{-1}$ for both ligands and complexes. $v(\mathrm{C}=\mathrm{S})$ band appeared in the ligands at $866 \mathrm{~cm}^{-1}$ and $825 \mathrm{~cm}^{-1}$ for MT24D and PT24D respectively and shifted to lower wavenumbers upon complexation of the ligands and $\mathrm{Ni}(\mathrm{II})$ ion in the region of $732-742 \mathrm{~cm}^{-1}$.

The electronic spectral analysis was carried out in DMSO and the data is displayed in Table 4. The bands at 261-280 and 300-353 nm were attributed to intra-ligand $n-\pi^{*}$ and $\pi-\pi^{*}$ transitions respectively [38]. Weak $d$ - $d$ transitions displayed at $400-500 \mathrm{~nm}$ indicated that the complexes had square planar geometry where the $\mathrm{Ni}(\mathrm{II})$ ion was coordinated to the azomethinenitrogen, hydroxyl-oxygen, thiolate-sulphur from the Schiff base, whereas the fourth position was occupied by the co-ligand, imidazole or benzimidazole. The appearance of a strong peak at 
347-377 nm additionally supported the ligation of sulphur to the metal ion via ligand to metal charge-transfer transitions.

\section{Table 3}

IR spectral bands of the Schiff bases and their mixed-ligand Ni (II) complexes

\begin{tabular}{lllllll}
\hline Compound & $v(\mathrm{O}-\mathrm{H})$ & $v(\mathrm{~N}-\mathrm{H})$ & $v(\mathrm{C}=\mathrm{N})^{\mathrm{a}, \mathrm{b}}$ & $v(\mathrm{~N}-\mathrm{N})$ & $v(\mathrm{C}=\mathrm{S})$ & $v(\mathrm{C}-\mathrm{S})$ \\
\hline MT24D & 3240 & 3336 & 1616 & 1013 & 866 & - \\
PT24D & 3160 & 3240 & 1592 & 1022 & 825 & - \\
$\mathbf{1}$ & 3076 & 3383 & 1600,1670 & 1071 & - & 732 \\
$\mathbf{2}$ & 3095 & 3394 & 1594,1748 & 1130 & - & 737 \\
$\mathbf{3}$ & 3049 & 3362 & 1596,1699 & 1022 & - & 742 \\
$\mathbf{4}$ & 3162 & 3353 & 1593,1700 & 1121 & - & 740 \\
\hline
\end{tabular}

${ }^{\mathrm{a}} \mathrm{C}=\mathrm{N}$ from ligand

${ }^{\mathrm{b}} \mathrm{C}=\mathrm{N}$ from imidazole/benzimidazole

\section{Table 4}

Electronic absorption bands of the Schiff bases and their mixed-ligand Ni (II) complexes

\begin{tabular}{ll}
\hline Compound & Electronic spectra (in DMSO) $\lambda_{\max }(\log \varepsilon)^{\mathrm{c}}$ \\
\hline MT24D & $280(3.08) ; 348(4.37)$ \\
PT24D & $279(4.11) ; 353(2.41)$ \\
$\mathbf{1}$ & $261(4.80) ; 301(3.92) ; 365(4.13) ; 406(3.99)$ \\
$\mathbf{2}$ & $279(4.81) ; 300(3.93) ; 369(4.09) ; 404(3.95)$ \\
$\mathbf{3}$ & $270(6.43) ; 304(6.48) ; 347(6.54) ; 406(7.61)$ \\
$\mathbf{4}$ & $280(4.87) ; 308(4.13) ; 377(4.23) ; 411(4.17)$ \\
\hline
\end{tabular}




\section{$3.3{ }^{1} \mathrm{H} N M R$ and ${ }^{13} \mathrm{C}$ NMR spectra}

To obtain insight and confirm the structure of the tridentate Schiff bases, ${ }^{1} \mathrm{H}$ NMR spectra of MT24D and PT24D (Figures S4 and S5, Supplementary Data) in DMSO- $d_{6}$ were obtained. The summary of the spectral data is shown in Tables S1 and S2 (Supplementary Data). The ${ }^{1} \mathrm{H}$ spectra MT24D showed a resonance in the downfield region around $\delta 11 \mathrm{ppm}$ which was assigned as the proton (H7) which was attached to the $\mathrm{N}$ atom. The existence of the electronegative atoms (nitrogen) adjacent this proton deshields the proton. One singlet peak at $\delta$ 8.35 and two singlets peaks at $\delta 9.55$ and $9.96 \mathrm{ppm}$ were observed correspond to $\mathrm{OH}$ phenolic of MT24D and PT24D, respectively. The aromatic protons were observed as multiplet ranging $\delta$ $6.62-7.33 \mathrm{ppm}$ corresponding to 3 protons and $\delta 6.64-7.51 \mathrm{ppm}$ corresponding to 8 protons for MT24D and PT24D, respectively. No resoance was observed at $\delta 4.0 \mathrm{ppm}$ which indicated the absence of the thiol group which proved that the Schiff bases were present in their thione tautomeric form in solution [39]. This is quite common, as the thioamide functional group, NH(CS)NR of the thiosemicarbazone Schiff bases is known to exhibit thione thiol tautomerism in solution [39].

The ${ }^{13} \mathrm{C}\left\{{ }^{1} \mathrm{H}\right\}$ NMR spectra and Distortionless Enhancement by Polarization Transfer (DEPT) experiments (Figures S6 and S7, Supplementary Data) were used to identify and assign the carbon atoms of the Schiff bases. The summary of the spectral data of MT24D and PT24D is shown in Table S2 (Supplementary Data). The signal due to the methyl group was observed at $\delta$ $31.38 \mathrm{ppm}$. The thiocarbonyl group $(-\mathrm{C}=\mathrm{S})$ was assigned at the region $\delta 176.23-177.12 \mathrm{ppm}$ in 
the most deshielded regions. All the other aromatic carbon shifts were observed in the region of $\delta$ $116.85-128.69 \mathrm{ppm}[15]$.

3.4 Crystal structures of $\quad[\mathrm{Ni}(\mathrm{PT} 24 \mathrm{D})(\mathrm{bz})](\mathrm{bz}) \cdot \mathrm{CH}_{3} \mathrm{OH} \quad\left(2^{\prime}\right) \quad$ and $\left[\mathrm{Ni}(\mathrm{MT2} 2 \mathrm{D})(\mathrm{im}) \mathrm{OO}_{2} \mathrm{CMe} .2 \mathrm{H}_{2} \mathrm{O}(5)\right.$

Crystal structure determinations were achieved for $\mathbf{2}^{\prime}$ and $\mathbf{5}$ with the molecular structures of each of the complex molecules shown in Fig. 1. The crystallographic asymmetric unit of $\mathbf{2}^{\prime}$ comprises a neutral complex molecule, a 1,3-benzimidazole molecule and a solvent methanol molecule. The tridentate di-anion coordinates the nickel(II) centre via thiolate-S1, phenoxide-O3 and imine-N3 atoms to establish five- and six-membered rings. The fourth site of the central atom is occupied by the N4 atom derived from a neutral benzimidazole molecule. The nitrogen atoms are mutually trans within the resultant $\mathrm{N}_{2} \mathrm{OS}$ donor set that defines an approximate square-planar geometry. Selected geometric data are given in Table 5 from which it can be seen that the maximum deviation from the ideal geometry, at least in terms of angles is found in the O1-Ni-N3 angle of $95.69(8)^{\circ}$.

The crystallographic asymmetric unit of $\mathbf{5}$ comprises a complex cation, an acetate anion and two water molecules of crystallisation. The tridentate mono-anion coordinates the nickel(II) centre via thione-S1, phenoxide-O3 and imine-N3 atoms. The fourth site of the central atom is occupied by the N4 atom derived from a neutral imidazole molecule. A very similar description of the coordination geometry pertains to the complex cation in $\mathbf{5}$ with the key difference being the thiolate-S1 donor in $\mathbf{2}^{\prime}$ is now a thione-S1 atom as the tridentate ligand is a mono-anion. The major angular deviation from the square-planar $\mathrm{N}_{2} \mathrm{OS}$ coordination geometry is again seen in the O1-Ni-N3 angle of $94.90(8)^{\circ}$. The experimental equivalence of the $\mathrm{C} 13-\mathrm{O} 3, \mathrm{O} 4$ bond lengths, 
i.e. 1.244(4) and 1.249(3) $\AA$, respectively, confirms the presence of the acetate counter-ion in the crystal of $\mathbf{5}$.

Systematic changes in key geometric parameters are evident in Table 5, as a result of the different coordination modes of the $\mathrm{LH}^{-}$and $\mathrm{L}^{2-}$ anions in $\mathbf{5}$ and $\mathbf{2}^{\prime}$, respectively. Most notable is the longer $\mathrm{Ni}-\mathrm{S} 1$ bond length in $\mathbf{5}$ compared with that in $\mathbf{2}$, with concomitant differences in the $\mathrm{Ni}-\mathrm{O} 1$ bond lengths. The short $\mathrm{C} 1-\mathrm{S} 1$ bond length in $\mathbf{5}$ is also consistent with the presence of a thione-S1 atom. Also, the C1-N2 length of 1.308(3) $\AA$ in 2 ' is consistent with the formation of an imine bond in the $\mathrm{L}^{2-}$ di-anion. This change is also reflected in some of the key angles, e.g. a reduction of ca $6^{\circ}$ in the $\mathrm{C} 1-\mathrm{N} 2-\mathrm{N} 3$ angle, and a decrease and increase by $5^{\circ}$ and $4^{\circ}$ in the $\mathrm{S} 1-\mathrm{C} 1-\mathrm{N} 1$ and S1-C1-N2 angles, respectively going from 5 to 2 '. 


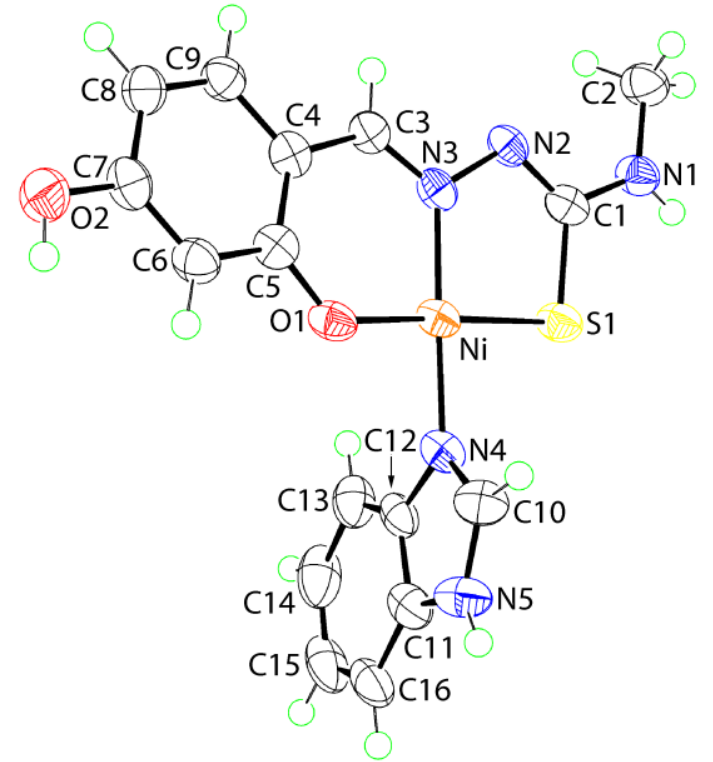

(a)

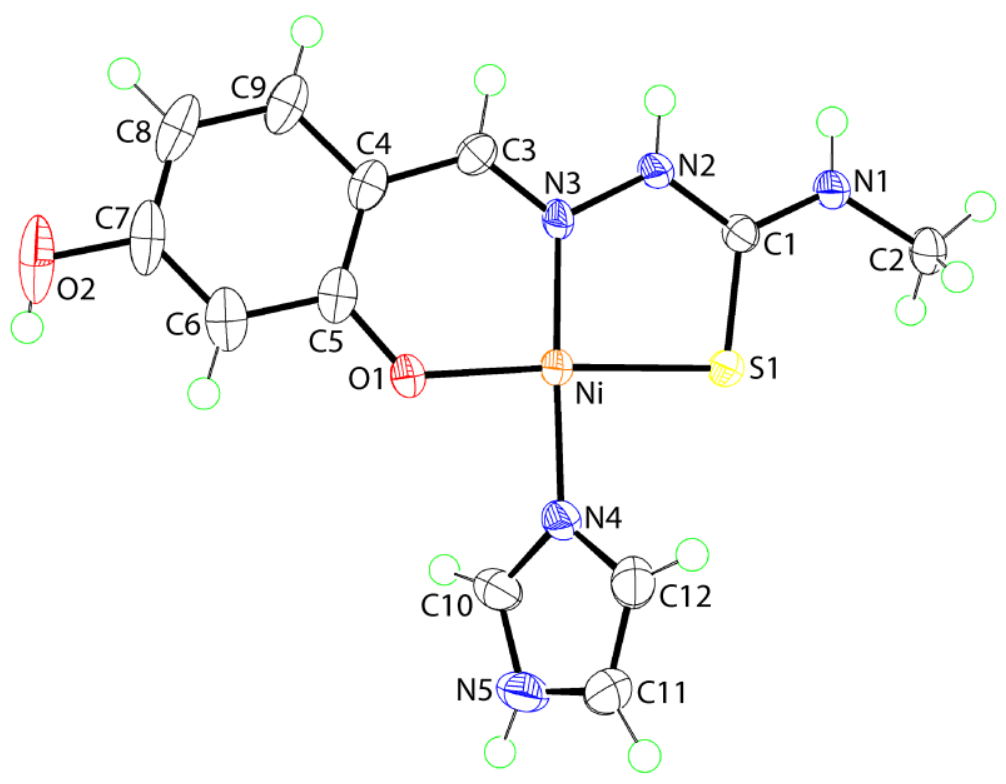

(b)

Fig. 1. Molecular structures of the complex molecules in (a) 2' and (b) 5, showing atom labelling schemes. 


\section{Table 5}

Selected geometric parameters $\left(\AA,^{\circ}\right)$ for $\mathbf{2}^{\prime}$ and $\mathbf{5}$.

\begin{tabular}{|c|c|c|}
\hline Complex & $2^{\prime}$ & 5 \\
\hline \multicolumn{3}{|l|}{ Parameter } \\
\hline $\mathrm{Ni}-\mathrm{S} 1$ & $2.1365(8)$ & $2.1545(7)$ \\
\hline $\mathrm{Ni}-\mathrm{O} 1$ & $1.8799(18)$ & $1.8597(17)$ \\
\hline $\mathrm{Ni}-\mathrm{N} 3$ & $1.862(2)$ & $1.853(2)$ \\
\hline $\mathrm{Ni}-\mathrm{N} 4$ & $1.897(2)$ & $1.894(2)$ \\
\hline $\mathrm{N} 2-\mathrm{N} 3$ & $1.417(3)$ & $1.397(3)$ \\
\hline $\mathrm{C} 1-\mathrm{S} 1$ & $1.744(2)$ & $1.715(2)$ \\
\hline $\mathrm{C} 1-\mathrm{N} 1$ & $1.350(3)$ & $1.326(3)$ \\
\hline $\mathrm{C} 1-\mathrm{N} 2$ & $1.308(3)$ & $1.453(3)$ \\
\hline $\mathrm{C} 3-\mathrm{N} 3$ & $1.304(3)$ & $1.301(3)$ \\
\hline $\mathrm{S} 1-\mathrm{Ni}-\mathrm{O} 1$ & $174.82(6)$ & $176.43(6)$ \\
\hline $\mathrm{S} 1-\mathrm{Ni}-\mathrm{N} 3$ & $87.54(7)$ & $88.60(6)$ \\
\hline $\mathrm{S} 1-\mathrm{Ni}-\mathrm{N} 4$ & $89.95(7)$ & $89.25(7)$ \\
\hline $\mathrm{O} 1-\mathrm{Ni}-\mathrm{N} 3$ & $95.69(8)$ & $94.90(8)$ \\
\hline $\mathrm{O} 1-\mathrm{Ni}-\mathrm{N} 4$ & $86.94(8)$ & $87.26(8)$ \\
\hline N3-Ni-N4 & 176.94(9) & 177.47(9) \\
\hline $\mathrm{C} 1-\mathrm{N} 2-\mathrm{N} 3$ & $111.4(2)$ & $117.4(2)$ \\
\hline N2-N3-C3 & $113.2(2)$ & $115.2(2)$ \\
\hline $\mathrm{S} 1-\mathrm{C} 1-\mathrm{N} 1$ & $117.7(2)$ & $122.78(19)$ \\
\hline $\mathrm{S} 1-\mathrm{C} 1-\mathrm{N} 2$ & $122.8(2)$ & 118.61(19) \\
\hline $\mathrm{N} 1-\mathrm{C} 1-\mathrm{N} 2$ & $119.4(2)$ & $118.6(2)$ \\
\hline
\end{tabular}


The tridentate mode of coordination of the $\mathrm{L}^{2-}$ and $\mathrm{LH}^{-}$anions in $\mathbf{2}^{\prime}$ and $\mathbf{5}$ results in the formation of five-membered $\mathrm{Ni}, \mathrm{S} 1, \mathrm{C} 1, \mathrm{~N} 2, \mathrm{~N} 3$ and six-membered Ni,O1,N3,C3-C5 chelate rings. While essentially planar, there are signficant deviations from planarity in the five-membered ring of $2^{\prime}$ : the r.m.s. deviation $=0.0210 \AA$ with the $\mathrm{N} 3$ atom deviating by $0.0290(12) \AA$ from this plane. Even more pronounced are the deviations in the six-membered chelate ring with the r.m.s. deviation for the fitted atoms being $0.0459 \AA$, and with the N3 and Ni atoms lying 0.0723(14) and 0.0559(10) $\AA$ to either side of the plane, respectively; the dihedral angle between the chelate rings $=6.19(10)^{\circ}$. Another description for the conformation of the six-membered chelate ring is one based on an envelope with the $\mathrm{Ni}$ atom being the flap atom, lying 0.152(3) $\AA$ out of the plane defined by the remaining five atoms [r.m.s. deviation $=0.0288 \AA$ ]. The coordinated 1,3 benzimidazole molecule [r.m.s. deviation $=0.0125 \AA$ occupies a position almost perpendicular to the tridentate ligand as seen in the dihedral of $88.94(6)^{\circ}$ formed between it and the fivemembered chelate ring. The non-coordinating 1,3-benzimidazole molecule is also planar [r.m.s. deviation $=0.0125 \AA$ ] . A difference in conformation in the chelate rings is evident in $\mathbf{5}$. In $\mathbf{5}$, both rings are planar with the greatest deviation from the five-membered ring [r.m.s. deviation $=$ 0.0091] being 0.0137(12) $\AA$ for the N3 atom. The equivalent parameters for the larger chelate ring are $0.0108 \AA$ and $0.0151(17) \AA$ for the C5 atom. The dihedral angle between the chelate rings is $0.861(9)^{\circ}$. The imidazole ring is inclined with respect to the rest of the molecule as seen in the dihedral angle of $50.69(7)^{\circ}$ it forms with the five-membered chelate ring.

The other obvious difference in conformation between the complex molecules in $\mathbf{2}$ ' and $\mathbf{5}$ relates to the relative orientations of the terminal amine-bound methyl groups. While in both molecules, this group is co-planar with the coordinated S1 atom with $\mathrm{S} 1-\mathrm{C} 1-\mathrm{N} 1-\mathrm{C} 2$ torsion 
angles of and $171.5(2)$ and $-1.87(16)^{\circ}$ in $\mathbf{2}$ and $\mathbf{5}$, respectively, in $\mathbf{5}$, the methyl group is syn to the $\mathrm{S} 1$ atom whereas there is an anti-relationship in $\mathbf{2}^{\prime}$.

The mode of coordination of the $\mathrm{LH}^{-}$anion in $\mathbf{5}$ appears to be unprecedented in the crystallographic literature according to a search of the Cambridge Structural Database [40]. Similarly, with a formal C3-C4 bond in 2', this is also unprecedented with the closest structural analogue being a nickel(II) complex where this bond is substituted by a bond of an aromatic ring [41].

As anticipated from the chemical compositions of $\mathbf{2}^{\prime}$ and $\mathbf{5}$, significant hydrogen bonding interactions are evident in their crystals. The geometric parameters characterising these along with other non-covalent interactions present in the respective crystals are tabulated in Table 6.

\section{Table 6}

Geometric parameters $\left(\AA,^{\circ}\right)$ characterising intermolecular interactions in the crystals of $\mathbf{2}^{\prime}$ and 5. ${ }^{a}$

\begin{tabular}{lllllll}
\hline A & H & B & H..B & A... & A-H..B & Symmetry operation \\
\hline $\mathbf{2}^{\prime}$ & & & & & & \\
O2 & H2o & N6 & $1.90(3)$ & $2.741(3)$ & $172(3)$ & $1-\mathrm{x}, 1-\mathrm{y},-\mathrm{z}$ \\
$\mathrm{O} 3$ & $\mathrm{H} 3 \mathrm{o}$ & $\mathrm{N} 2$ & $1.982(13)$ & $2.805(3)$ & $164(4)$ & $1-\mathrm{x}, 1-\mathrm{y}, 1-\mathrm{z}$ \\
$\mathrm{N} 5$ & $\mathrm{H} 5 \mathrm{n}$ & $\mathrm{O} 3$ & $1.927(14)$ & $2.804(3)$ & $175(3)$ & $1+\mathrm{x}, \mathrm{y}, \mathrm{z}$ \\
$\mathrm{N} 7$ & $\mathrm{H} 7 \mathrm{n}$ & $\mathrm{O} 1$ & $1.96(3)$ & $2.833(3)$ & $169(3)$ & $-1+\mathrm{x}, \mathrm{y}, \mathrm{z}$ \\
$\mathrm{N} 1$ & $\mathrm{H} 1 \mathrm{n}$ & $\mathrm{Cg}(1)$ & $2.68(2)$ & $3.480(2)$ & $153.7(18)$ & $1+\mathrm{x}, \mathrm{y}, 1+\mathrm{z}$
\end{tabular}

5

N1 H1n O3 $1.937(18) \quad 2.808(3) \quad 173(3) \quad 1-\mathrm{x}, 1-\mathrm{y}, 1-\mathrm{z}$




$\begin{array}{lllllll}\mathrm{N} 2 & \mathrm{H} 2 \mathrm{n} & \mathrm{O} 4 & 1.842(17) & 2.718(3) & 176(3) & 1-\mathrm{x}, 1-\mathrm{y}, 1-\mathrm{z} \\ \mathrm{O} 2 & \mathrm{H} 2 \mathrm{o} & \mathrm{O} 2 \mathrm{w} & 1.99(2) & 2.825(4) & 172(3) & \mathrm{x}, \mathrm{y}, \mathrm{z} \\ \mathrm{N} 5 & \mathrm{H} 5 \mathrm{n} & \mathrm{O} 1 \mathrm{w} & 1.90(2) & 2.759(3) & 167(3) & -\mathrm{x}, 1-\mathrm{y},-\mathrm{z} \\ \mathrm{O} 1 \mathrm{w} & \mathrm{H} 1 \mathrm{w} & \mathrm{O} 1 & 2.01(3) & 2.852(3) & 177(3) & \mathrm{x}, \mathrm{y}, \mathrm{z} \\ \mathrm{O} 1 \mathrm{w} & \mathrm{H} 2 \mathrm{w} & \mathrm{O} 4 & 1.93(3) & 2.763(3) & 171(3) & \mathrm{x}, \mathrm{y}, \mathrm{z} \\ \mathrm{O} 2 \mathrm{w} & \mathrm{H} 3 \mathrm{w} & \mathrm{O} 3 & 1.96 & 2.678(5) & 145 & 1-\mathrm{x},-\mathrm{y},-\mathrm{z} \\ \mathrm{O} 2 \mathrm{w} & \mathrm{H} 4 \mathrm{w} & \mathrm{O} 4 & 2.67 & 3.438(4) & 154 & \mathrm{x}, \mathrm{y}, \mathrm{z}\end{array}$

${ }^{a} \mathrm{Cg}(1)$ is the ring centroid of the $\mathrm{C} 18-\mathrm{C} 23$ ring.

Hydrogen bonding interactions also feature prominently in the molecular packing of $\mathbf{2}^{\prime}$. The hydroxyl group of the complex molecule forms a hydroxyl-O- $\mathrm{H} \cdots \mathrm{N}$ (benzimidazole) hydrogen bond with a lattice benzimidazole molecule which, in turn, forms a benzimidazole-N$\mathrm{H}^{\cdots} \mathrm{O}$ (methanol) hydrogen bond. The solvent molecule functions in the same way by forming methanol-O- $\mathrm{H}^{\cdots \cdots} \mathrm{N}\left(\right.$ imine) and coordinated-benzimidazole- $\mathrm{N}-\mathrm{H}^{\cdots} \mathrm{O}$ (methanol) hydrogen bonds. The result is a supramolecular chain along the c-axis direction as shown in Fig. 2(a). While there is no role formal role for the amine- $\mathrm{N}-\mathrm{H}$ hydrogen in the hydrogen bonding scheme, this atom participates in the molecular packing by forming in a $\mathrm{N}-\mathrm{H}^{\cdots} \pi\left(\mathrm{C}_{6}\right.$-benzimidazole $)$ interaction within the supramolecular chain as detailed in Fig. 2(b). The chains are connected into a supramolecular layer in the bc-plane by $\pi \cdots \pi$ stacking interactions between symmetry related benzimidazole rings, i.e. $(\mathrm{N} 4, \mathrm{~N} 5, \mathrm{C} 10-\mathrm{C} 12)$ and $(\mathrm{C} 11-\mathrm{C} 16)^{\mathrm{i}}$ rings with an inter-centroid separation of 3.6142(16) $\AA$ and angle of inclination $=1.23(14)^{\circ}$; symmetry operation (i): 2 -x, 2 y, 1-z. Layers stack along the a-axis direction without directional interactions between them, Fig. 2(c). 


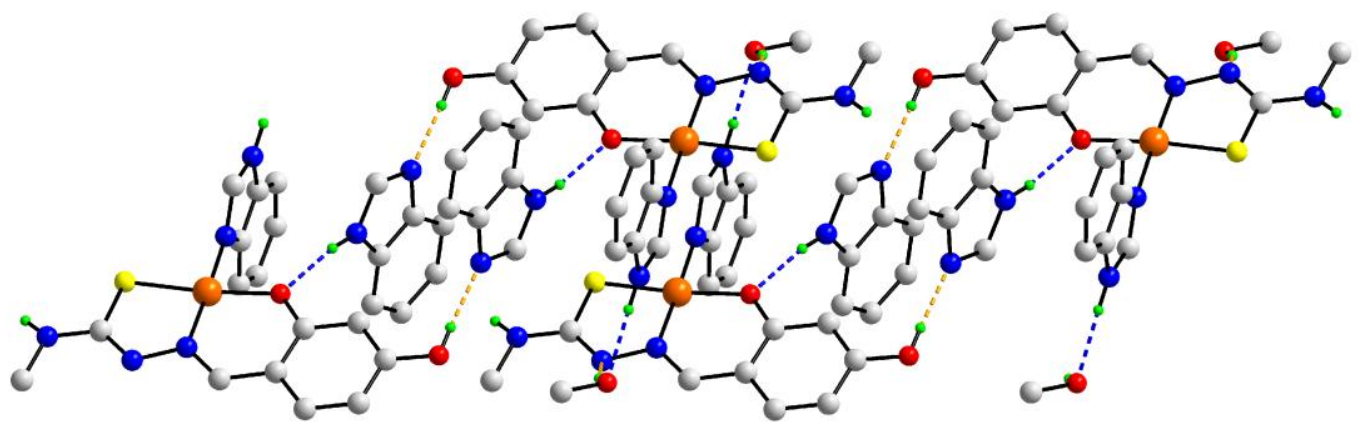

(a)

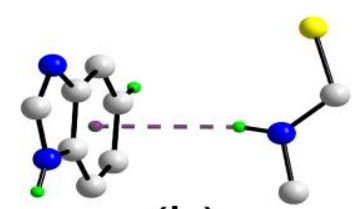

(b)

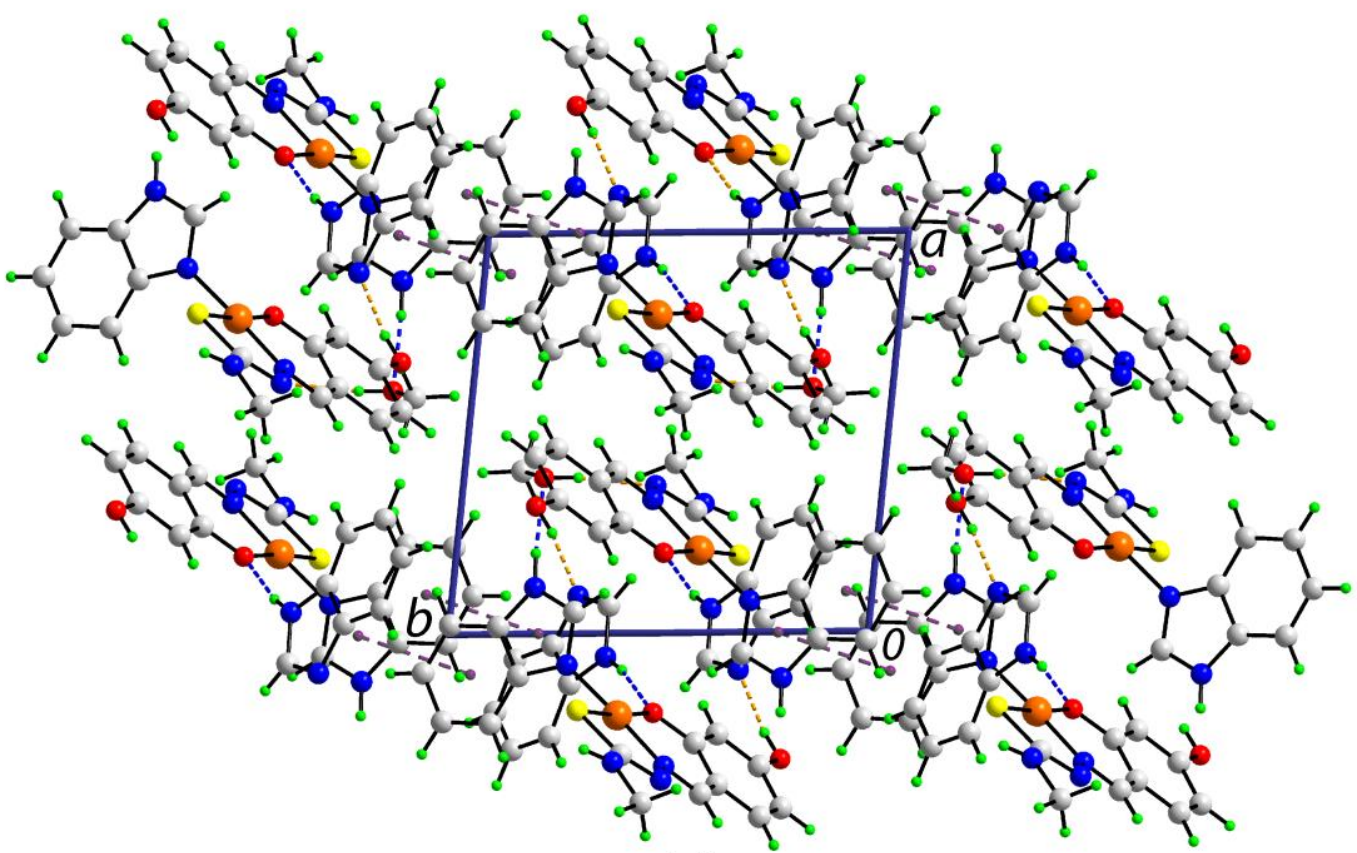

(c)

Fig. 2. Supramolecular association in the crystal of 2: (a) a view of the supramolecular chain along the c-axis direction and sustained by $\mathrm{O}-\mathrm{H} \cdots \mathrm{N}$ and $\mathrm{N}-\mathrm{H}^{\cdots} \mathrm{O}$ hydrogen bonding shown as orange and blue dashed lines, respectively, (b) detail of the amine- $\mathrm{N}-\mathrm{H} \cdots \pi$ interaction 
highlighted as a purple dashed line and (c) a view in projection down the c-axis of the unit cell contents of $\mathbf{1}$ with $\pi \cdots \pi$ interactions shown as purple dashed lines.

In the crystal of $\mathbf{5}$, the acetate anion spans the two amine- $\mathrm{N}-\mathrm{H}$ atoms via two chargeassisted amine- $\mathrm{N}-\mathrm{H} . . \mathrm{O}$ (carboxylate) hydrogen bonds to form an eight-membered $\{\cdots \mathrm{OCO} \cdots \mathrm{HNCNH}\}$ heterosynthon. The presence of hydroxyl-O- $\mathrm{H} \cdots \mathrm{O} 2 \mathrm{w}$ (water), imidazole-N$\mathrm{H}^{\cdots \cdots} \mathrm{O} 1 \mathrm{w}\left(\right.$ water) and water-O $1 \mathrm{w}^{\cdots \cdots} \mathrm{O} 2$ (phenoxide) hydrogen bond provide further links between the complex cation and the other constituents of the crystal. Each of the carboxylate-O atoms forms a water-O- $\mathrm{H}^{\cdots} \mathrm{O}$ (carboxylate) hydrogen bond, derived from different water molecules. Finally, the $\mathrm{H} 4 \mathrm{w}$ atom participates in a long hydrogen bond with the carboxylate-O4 atom. A view of the unit cell contents is shown in Fig. 3. From here, globally, complex cations stack along the crystallographic a-axis and are connected into a three-dimensional architecture via the aforementioned hydrogen bonds which extend laterally from the columns. 


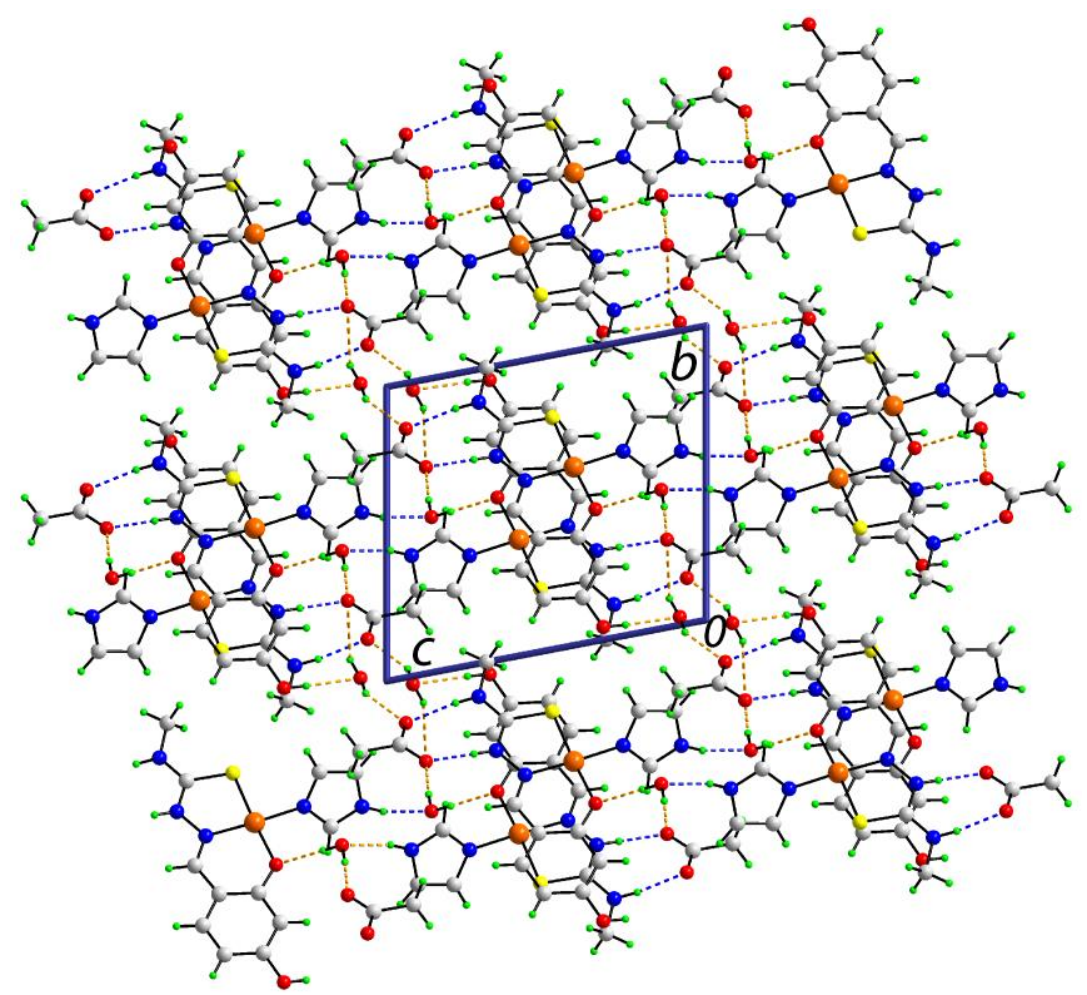

Fig. 3. A view in projection down the a-axis of the unit cell contents of 5. The $\mathrm{O}-\mathrm{H} \cdots \mathrm{O}$ and $\mathrm{N}-$ $\mathrm{H}^{\cdots \cdots} \mathrm{O}$ hydrogen bonds are shown as orange and blue dashed lines, respectively.

\section{Biological activities}

\subsection{Cytotoxic activities}

The cytotoxicity studies of Schiff bases and mixed-ligand $\mathrm{Ni}(\mathrm{II})$ complexes were screened against two selected breast cancer cell lines, MCF-7 (human breast cancer with positive estrogen receptor) and MDA-MB-231 (human breast cancer with negative estrogen receptor). The $\mathrm{IC}_{50}$ values (concentration of drug that inhibits the growth of cancer cells by $50 \%$ as compared to the untreated controls) were determined. $\mathrm{An} \mathrm{IC}_{50}$ value of less than $0.5 \mu \mathrm{M}$ indicates that the complex is strongly active, whereas $\mathrm{IC}_{50}$ values of $0.5-5.0 \mu \mathrm{M}$ and more than $5.0 \mu \mathrm{M}$ indicate that the complex is moderately active and inactive, respectively [42]. The data obtained 
showed all the compounds were inactive against the tested cancer cell lines. This could have been due to the presence of a hydroxyl group in the Schiff bases of $\mathrm{Ni}$ (II) complexes that reduced the cytotoxicity, probably due to the greater steric hindrance and intramolecular $\mathrm{H}$ bonding between the compounds [43]. Interestingly however, the PT24D and Ni(II) complexes were observed to have antibacterial potency against the bacterial strains tested.

\subsection{Antibacterial activities}

The Schiff bases, and mixed-ligand Ni(II) complexes were screened for their antibacterial properties against Staphylococcus aureus, Bacillus subtilis, Propionibacterium acne (Grampositive), and Pseudomonas aeruginosa, Serratiamarcescens, Enterobacteraerogenes (Gramnegative). Streptomycin was used as a positive control and DMSO used as negative control in the antibacterial studies. The disc diffusion assay data is tabulated in Table 7 while the minimum inhibition concentration (MIC) and minimum bacterial concentration (MBC) results are recorded in Table 8.

The mixed-ligand $\mathrm{Ni}(\mathrm{II})$ complexes were observed to have better antibacterial activity compared to the Schiff bases suggesting that the metal ions reduced the polarity of the compounds through the partial sharing of positive charge with the donor atoms of Schiff bases [44]. Hence, $\pi$-electron delocalisation upon chelation which also increased the lipophilic character of the central metal atom allowed the $\mathrm{Ni}(\mathrm{II})$ complexes to have a stronger permeating ability to enter the permeable membrane of the bacterial strains [45]. This was also observed in similar mixed-ligand $\mathrm{Ni}(\mathrm{II})$ complexes with sap (salicylidene-2-aminophenol) and imidazole which had significant antibacterial activities compared to other $\mathrm{Ni}(\mathrm{II})$ complexes containing only 2-carboxybenzaldehyde thiosemicarbazone $[46,47]$. The complexes in this study seemed to 
be more bacteriocidal towards the gram-positive bacteria tested. Complex 2 had the smallest MIC and MBC values against Pseudomonas Aeruginosa whereas Complex $\mathbf{1}$ had small MIC and MBC values against a range of both positive and negative gram bacteria, suggesting that only small amounts of the metal complex were needed to inhibit/kill the growth of the microorganism [48]. 
Table 7

Disc diffusion assay of the Schiff bases and mixed-ligand Ni(II) complexes against selected bacterial strains.

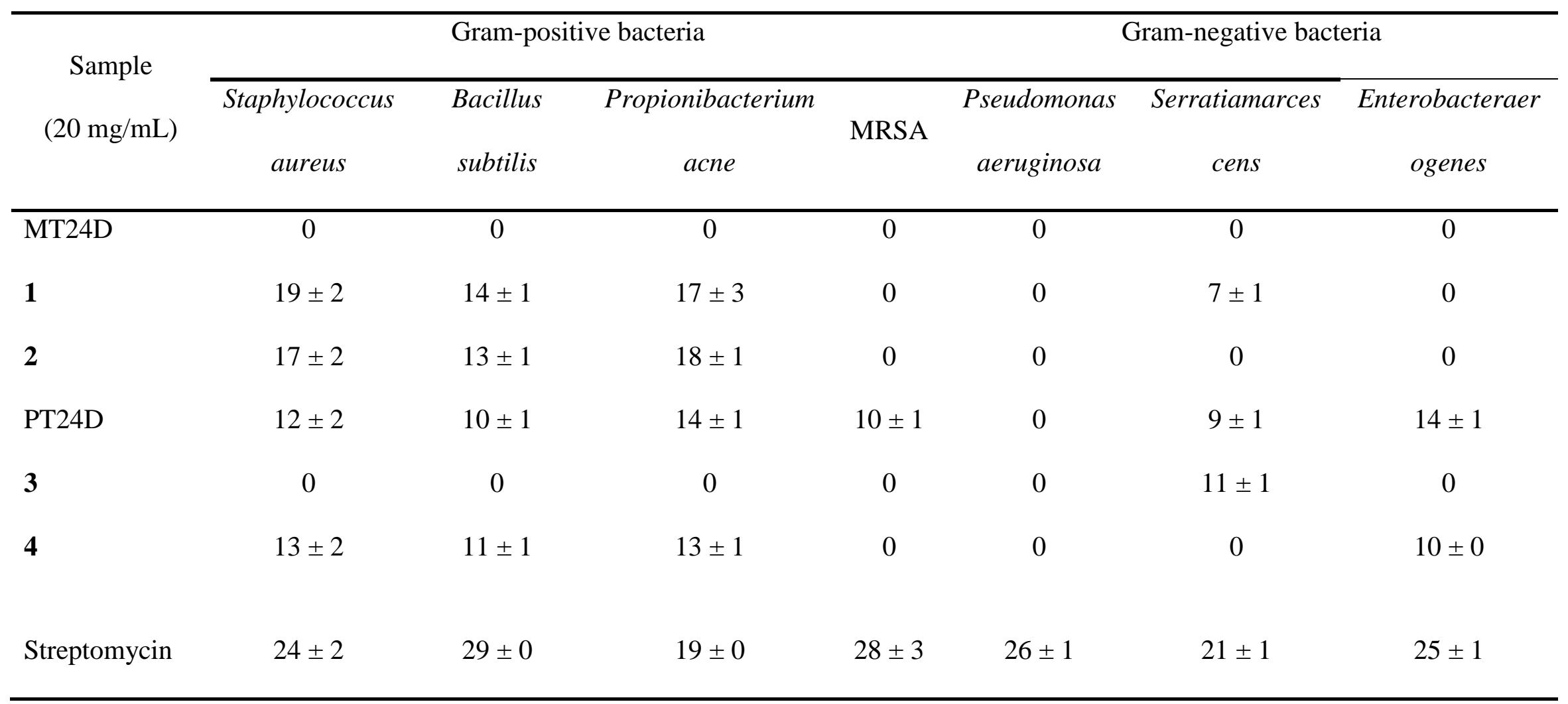

${ }^{\text {a }}$ Diameter of $\mathbf{1 5} \mathbf{~ m m}$ and above is considered active; 0 , inactive. 
Table 8

Results of minimum inhibitory concentration (MIC) and minimum bactericidal concentration (MBC) (results are in mg/mL).

\begin{tabular}{lcccccccc}
\multirow{2}{*}{ Sample } & \begin{tabular}{c} 
Staphylococcus \\
\cline { 2 - 8 }
\end{tabular} & \multicolumn{2}{c}{$\begin{array}{c}\text { Bucillus } \\
\text { aureus }\end{array}$} & \multicolumn{2}{c}{ subtilis } & \multicolumn{2}{c}{ Propionibacterium } & \multicolumn{2}{c}{ Enterobacteraerogenes } \\
\cline { 2 - 8 } & MIC & MBC & MIC & MBC & MIC & MBC & MIC & MBC \\
\hline $\mathbf{1}$ & 0.63 & 1.25 & 10.0 & 20.0 & 0.63 & 1.25 & - & - \\
$\mathbf{2}$ & 1.25 & 2.50 & - & - & 0.16 & 0.31 & - & - \\
PT24D & - & - & - & - & - & - & 10.0 & 20.0 \\
$\mathbf{4}$ & 10.0 & 20.0 & - & - & - & - & - & - \\
\hline
\end{tabular}




\subsection{DNA-binding studies}

Electronic absorption spectroscopy is a universal technique used to investigate the strength and mode of binding interactions between compounds 1 and $\mathbf{2}$ with CT-DNA [34]. The UV spectra of $\mathbf{1}$ and $\mathbf{2}$ in the absence and presence of CT-DNA is given in Figs. 4 and 5, respectively. Both spectra exhibited hypochromism of $17.2 \%$ and $23.4 \%$ for $\mathbf{1}$ and $\mathbf{2}$, respectively indicating that the $\pi$ orbital of aromatic chromophore of the complexes interacted with $\pi$ orbital of nucleobases of DNA [49]. The intrinsic binding constant $K_{\mathrm{b}}$ of the complex with CT-DNA was determined according to the following equation [4]:

$$
[\mathrm{DNA}] /\left(\varepsilon_{\mathrm{a}}-\varepsilon_{\mathrm{f}}\right)=[\mathrm{DNA}] /\left(\varepsilon_{\mathrm{b}}-\varepsilon_{\mathrm{f}}\right)+1 / K_{\mathrm{b}}\left(\varepsilon_{\mathrm{b}}-\varepsilon_{\mathrm{f}}\right)
$$

where [DNA] is the concentration of DNA in the base pairs, $K_{\mathrm{b}}$ is the intrinsic binding constant, $\varepsilon_{\mathrm{a}}$ corresponds to the apparent extinction coefficient, and $\varepsilon_{\mathrm{b}}$ and $\varepsilon_{\mathrm{f}}$ correspond to the extinction coefficients of the bound and free forms of the complex, respectively. The $K_{\mathrm{b}}$ value obtained for 1 was $4.2 \times 10^{2} \mathrm{M}^{-1}$ while for 2 it was $5.7 \times 10^{3} \mathrm{M}^{-1}$ which was high, an indication of strong and stable interactions between the complexes and CT-DNA [50, 51]. Comparing the molecular structures of both the complexes, it was expected that the greater number of coplanar aromatic rings in the latter could have led to a higher affinity for DNA [52]. The interaction between 2 and DNA was also better than 1 possibly due to the presence of aromatic benzimidazole rings where the nitrogen atom of benzimidazole interacted well with the nucleobases of DNA. However, despite good $K_{\mathrm{b}}$ values, both complexes had weaker interactions as compared to the interaction of the standard, ethidium bromide with the DNA base pairs $\left(K_{\mathrm{b}}: 7 \times 10^{7} \mathrm{M}^{-1}\right)$ [53]. 


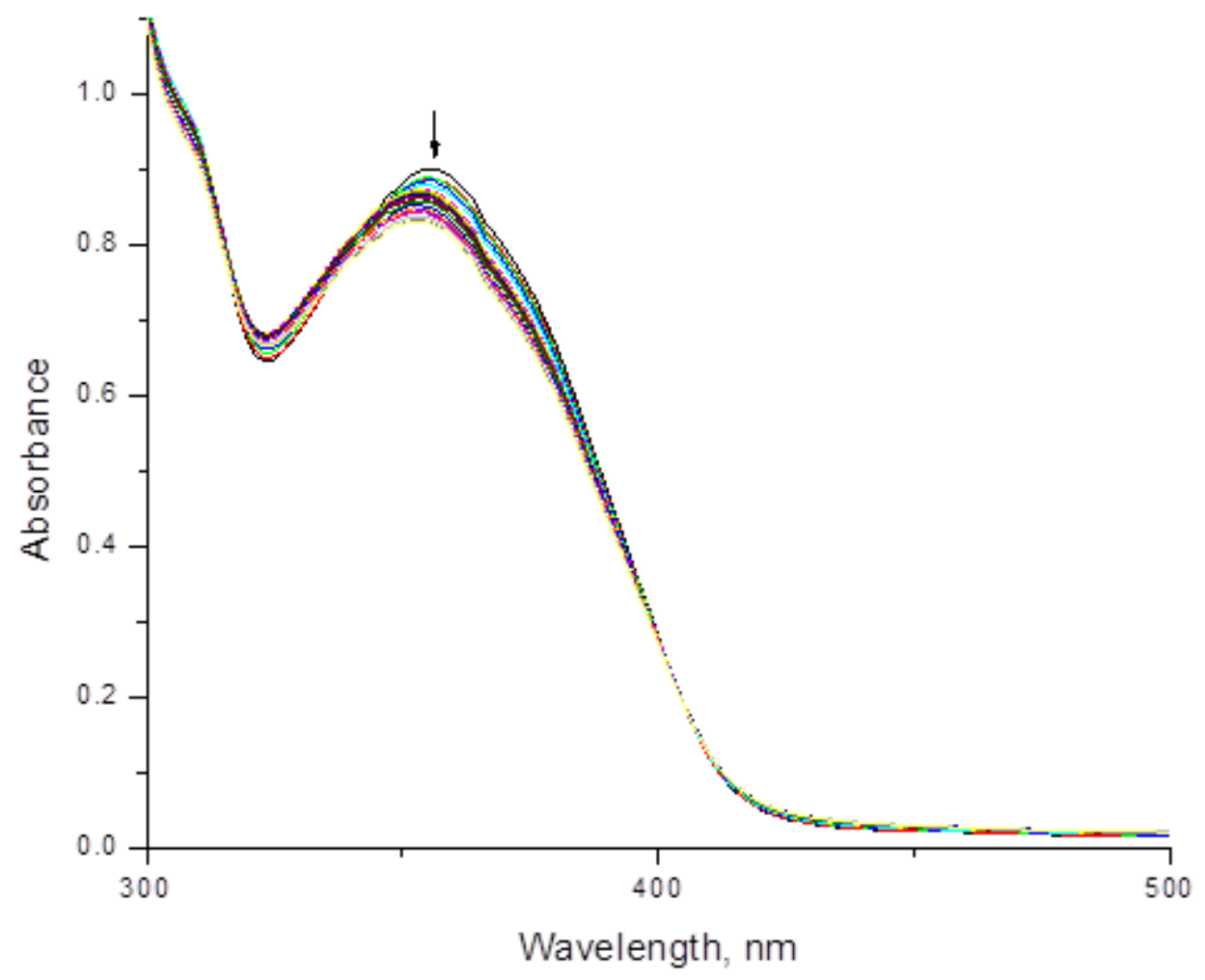

Fig. 4. Electronic spectra of $\mathbf{1}$ in Tris-HCl buffer upon addition of CT-DNA. The arrow shows the emission intensity changes upon increasing DNA concentration from $0 \mathrm{uL}$ DNA to $240 \mathrm{uL}$ DNA. 


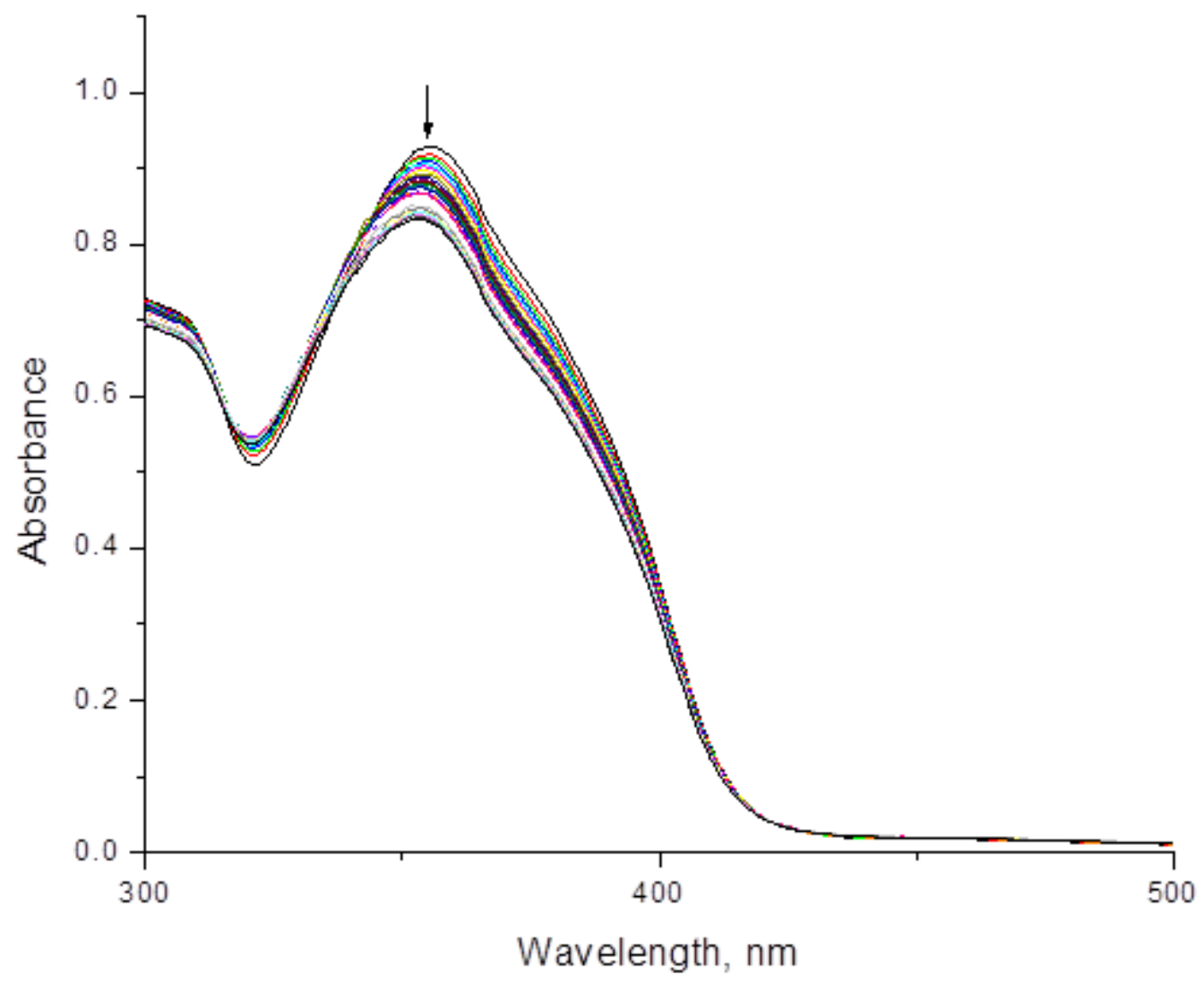

Fig. 5. Electronic spectra of 2 in Tris-HCl buffer upon addition of CT-DNA. The arrow shows the emission intensity changes upon increasing DNA concentration from 0 uL DNA to $240 \mathrm{uL}$ DNA.

\section{Conclusions}

The reaction of $\mathrm{Ni}$ (II) acetate with Schiff bases derived from 4-substituted-3thiosemicarbazide and 2,4-dihydroxybenzaldehyde in the presence of imidazole or benzimidazole yielded a new series of mixed-ligand Ni(II) complexes, 1-4. The Schiff bases coordinated to the $\mathrm{Ni}(\mathrm{II})$ ion via deprotonated ONS donor atoms and a monodentate nitrogen atom from imidazole or benzimidazole, yielding a distorted square planar geometry as was supported by spectroscopic analysis. Indirect evidence for the proposed structures were provided 
by crystallographic methods. X-ray crystallography established the complex in $\mathbf{2}^{\prime}$ and complex cation in $\mathbf{5}$ and to exist within trans- $\mathrm{N}_{2} \mathrm{OS}$ square planar coordination geometry. In $\mathbf{5}$, the sulphur atom is a thione as opposed to a thiolate in $\mathbf{2}^{\prime}$. The form (charge) of the tridentate ligand gave rise to systematic changes in bond lengths and angles. Considerable hydrogen bonding led to a three-dimensional architecture in the crystal of 5 but, only one-dimensional chains in 2'. All the tested compounds were inactive against the two selected breast cancer cell lines. Although the complexes had higher activity than their free Schiff bases against the tested microbes, their $K_{\mathrm{b}}$ values were significantly lower than the standard, indicating that the complexes had a different mode of action against the tested cancer cells and microbes in this work.

\section{Acknowledgements}

We thank the Faculty of Science, the Faculty of Medicine and Health Science at Universiti Putra Malaysia (UPM) and the Institute of Bioscience, Universiti Putra Malaysia for the provision of laboratory facilities. The research was funded by UPM under University Grant Scheme (IPS 9548700 and IPB 9581001) and the Malaysian Fundamental Research Grant Scheme (FRGS No. 5524940).

\section{Appendix A. Supplementary material}

Crystallographic data for $\mathbf{1}$ and $\mathbf{2}$ reported in this paper have been deposited with the Cambridge Crystallographic Data Centre (CCDC) as supplementary publication nos 1919663 (2') and 1919664 (5).

These data can be obtained free of charge via www.ccdc.cam.ac.uk/getstructures. Crystallographic diagrams and details of intermolecular interactions are given in Figures 1-3 and Tables 1, 5 and 6. 


\section{References}

[1] P. Krishnamoorthy, P. Sathyadevi, A.H. Cowley, R.R. Butorac, N. Dharmaraj, Eur. J. Med. Chem. 46 (2011) 3376-3387.

[2] F. Arjmand, A. Jamsheera, D.K. Mohapatra, J. Photochem. Photobiol. 121B (2013) 7585.

[3] R.P. Bonomo, E. Conte, G. De Guidi, G. Maccarrone, E. Rizzarelli, G.J. Vecchio, J. Chem. Soc, Dalton Trans. 23 (1996) 4351-4355.

[4] X. Li, C.-F. Bi, Y.-H. Fan, X. Zhang, X.-D. Wei, X.-M. Meng. Transit. Metal Chem, 39 (2014) 577-584. Same as [34]

[5] J. Haribabu, K. Jeyalakshmi, Y. Arun, N. S. P. Bhuvanesh, P.T. Perumal, Karvembu, R. J. Biol. Inorg. Chem, 22 (2017) 461-480.

[6] M.M. Tamizh, B.F.T. Cooper, C.L.B. Macdonald, R. Karvembu, Inorg. Chim. Acta, vol (2013) 391-394.

[7] M. Kalita, T. Bhattacharjee, P. Gogoi, P. Barman, R.D. Kalita, B. Sarma, S. Karmakar, Polyhedron 60 (2013) 47-53.

[8] Zafer Asım Kaplancıkl1, Mehlika Dilek Altıntop, Belgin Sever, Zerrin Cantürk, and Ahmet Özdemir J. Chem. (2016) ID 1692540.

[9] M. Serda, D.S. Kalinowski, N. Rasko, E. Potůčková, A. Mrozek-Wilczkiewicz, R. Musiol, PLoS ONE 9 (2014) e110291.

[10] K.C. Park, L. Fouani, P.J. Jansson, D. Wooi, S. Sahni, D.J.R. Lane, D.R. Richardson, Metallomics 8 (2016) 874-886.

[11] P.F. Salas, C. Herrmann, C. Orvig, Chem. Rev. 113 (2013) 3450-3492. 
[12] S. Kathiresan, S. Mugesh, J. Annaraj, M. Murugan, New J. Chem. 41 (2017) 1267-1283.

[13] M. Abid, S.M. Agarwal, A. Azam, Eur. J. Med. Chem. 43 (2008) 2035-2039.

[14] V. Mahalingam, N. Chitrapriya, F.R. Fronczek, K. Natarajan, Polyhedron 27 (2008) 2743-2750.

[15] I. Dilovic, M. Rubcic, V. Vrdoljak, S.K. Pavelic, M. Kralj, C.I.M. Piantanida, Bioorg. Med. Chem. 16 (2008) 5189-5198.

[16] N.A. Mazlan, T.B.S. Ravoof, E.R.T. Tiekink, M.I.M. Tahir, A. Veerakumarasivam, K.A. Crouse, 39(6) (2014) 633-639.

[17] M. Heijden, P.M.V. Vliet, J.G. Haasnoot, J. Reedijk, Dalton Trans. 24 (1993) 3675-3679.

[18] A. Puratchikody, M. Doble, Bioorg. Med. Chem. 15 (2007) 1083-1090.

[19] F. Bellina, S. Cauteruccio, R. Rossi, Tetrahedron 63 (2007) 4571-4624.

[20] R. Di Santo, A. Taf, R. Costi, J. Med. Chem. 48 (2005) 5140-5153.

[21] S. Dutta, Acta Pharmaceutica, 60 (2010) 229-235.

[22] D.M.L. Goodgame, M. Goodgame, G.W. Rayner-Canham, Inorg. Chim. Acta 3 (1969) 406-410.

[23] K. Brandenburg, DIAMOND, Crystal Impact (2006) GbR, Bonn

[24] T. B. Ravoof, K. A. Crouse, M. I. M Tahir, A. R. Cowley, M. A. Ali, 23(16) (2004) 2491-2498.

[25] Agilent Technologiers. CrysAlis PRO. Agilent Technologies Inc., 2011.

[26] G.M. Sheldrick, A short history of SHELX, Acta Crystallogr. Sect. A Found. Crystallogr. 64 (2008) 112-122.

[27] G.M. Sheldrick, Crystal structure refinement with SHELXL, Acta Crystallogr. Sect. C Struct. Chem. 71 (2015) 3-8. 
[28] L.J. Farrugia, WinGX and ORTEP for Windows: An update, J. Appl. Crystallogr. 45 (2012) 849-854.

[29] K. Brandenburg, DIAMOND, Crystal Impact GbR, (2006).

[30] A. L. Spek, Acta Crystallogr. Sect. D: Biol. Crystallogr. 65 (2009) 148-155.

[31] T. Mosmann, J. Immunol Methods (1983) 65-72.

[32] M. Balouiri, M. Sadiki, S. K. Ibnsouda, J. Pharm. Anal. 6 (2016) 71-79.

[33] Y. Wang, J.W. Mao, C. Ding, Z.Q. Pan, J.F. Li, H. Zhou, Transit. Metal Chem. 39 (2014) $111-118$.

[34] X. Li, C.F. Bi, Y.H. Fan, X. Zhang, X.D. Wei, X.M. Meng, Transit. Met. Chem. 39 (2014) 577-584. Same as [4]

[35] M.A. Ali, M.T.H. Tarefder, J. Inorg. Nucl. Chem. 39 (1977) 1785-1791.

[36] J.F. Dong, L.Z. Li, L.W. Li, T. Xu, D.Q. Wang, Chin. J. Chem. vol? (2011) 259-268.

[37] J.R. Dilworth, R. Hueting, Inorg. Chim. Acta vol? (2012) 389-392.

[38] R.N. Patel, V.L.N. Gundla, D.K. Patel, Polyhedron 27 (2008) 1054-1060.

[39] V. Vrdoljak, M. Cindric, D. Milic, D. Matkovic-Calogovic, P. Novak, B. Kamenar, Polyhedron 24 (2005) 1717-1726.

[40] C.R. Groom, I.J. Bruno, M.P. Lightfoot, S.C. Ward, S.C. The Cambridge Structural Database. Acta Crystallogr. Sect. B Struct. Sci. Cryst. Eng. Mater. 72 (2016) 171-179.

[41] Z. Afrasiabi, P. Stovall, K. Finley, A. Choudhury, C. Barnes, A. Ahmad, F. Sarkar, A. Vyas, S. Padhye. Spectrochim. Acta Part A 114 (2013) 114-119.

[42] C.K. Chah, T.B.S.A. Ravoof, A. Veerakumarasivam, Initial? Pertanika J. Sci. Technol. 26 (2018) 653-670. 
[43] J.V. Duncia, J.B. Santella, C.A. Higley, W.J. Pitts, J. Wityak, W.E. Frietze, R.E. Olson, Bioorg. Med. Chem. Lett. 8 (1998) 2839-2844.

[44] K. Singh, R. Thakur, V. Kumar, J. Basic Appl. Sci. 5(2016) 21-30.

[45] E. Ispir, Dyes Pigm. 82 (2009) 13-19.

[46] M. Salehi, F. Rahimifar, M. Kubicki, A. Asadi, Inorg. Chim. Acta 443 (2016) 28-35.

[47] S. Chandra, Vandana, Spectrochim. Acta A Mol. Biomol. Spectrosc. 129 (2014) 333-338.

[48] M.R. Mlahi, O.A. El-Gammal, M.H. Abdel-Rhman, I.M. AbdAl-Gader, J. Mol. Struct. 1182 (2019) 168-180.

[49] X. Wang, Y. Du, L. Fan, H. Liu, Y. Hu, Polym. Bull. 55 (2005) 105-113.

[50] S. Arounaguiri, D. Easwaramoorthy, A. Ashokkumar, A. Dattagupta, B.G. Maiya. J. Chem. Sci. 112 (2000) 1-17.

[51] S. Mathur, S. Tabassum. Cent. Eur. J. Chem. 4 (2006) 502-522.

[52] H. Wu, F. Shi, X. Wang, Y. Zhang, Y. Bai, J. Kong, C. Wang, Transit. Metal Chem. 39 (2014) 261-270.

[53] M. J. Waring, J. Mol. Biol. 13 (1965) 269-282. 